\title{
Measurement of return on marketing investment: A conceptual framework and the future of marketing metrics
}

\author{
Steven H. Seggie ${ }^{a, *}$, Erin Cavusgil ${ }^{\text {b,1 }}$, Steven E. Phelan ${ }^{c, 2}$ \\ ${ }^{a}$ Faculty of Business Administration, Bilkent University, 06800 Bilkent Ankara, Turkey \\ ${ }^{\mathrm{b}}$ Department of Marketing and Supply Chain Management, Michigan State University, N471 Business College Complex, East Lansing, MI 48824, USA \\ ' Department of Management, University of Nevada, Las Vegas 4505 Maryland Parkway Box 456009, Las Vegas, NV 89154-6009, USA
}

Received 20 October 2004; received in revised form 31 January 2006; accepted 1 November 2006

Available online 9 January 2007

\begin{abstract}
There is growing recognition that firms in the contemporary business environment derive substantial and sustained competitive advantage from a bundle of intangible assets such as knowledge, networks and innovative capability. Measuring the return on such intangible assets has now become imperative for managers. The present manuscript focuses on the measurement of the return on marketing. We first discuss the conditions that make this task a high managerial priority. We then discuss measurement efforts to date, both in general management and marketing. We then offer a conceptual framework that places measurement efforts in a historical perspective. We conclude with a discussion on where the future of marketing metrics lies.

(C) 2006 Elsevier Inc. All rights reserved.
\end{abstract}

Keywords: Marketing returns; Intangible assets; Marketing metrics; Value added

In recent years there has been a drive within both industry and academia to provide suitable measures that can be employed in evaluating the "value-added" of, especially, the functional specialists within the firm. Accounting measures that may have worked in the industrial age are no longer uniquely capable of measuring performance in the post-industrial epoch (Kaplan \& Norton, 1992).

In addition, functional business areas that have proven particularly resistant to measurement are more so being called to account. One of these areas is marketing, with increasing calls made by senior executives regarding the need to measure the return on investment in marketing (e.g., Clancy \& Stone, 2005). Marketing has had limited input into strategy formulation (Srivastava, Shervani, \& Fahey, 1998), and one of the reasons for this has been the inability of marketers to identify and measure the value that they bring to the firm. Marketers have blamed themselves for not linking marketing to quantifiable

\footnotetext{
* Corresponding author. Tel.: + 903122901276.

E-mail addresses: steven@bilkent.edu.tr (S.H. Seggie), cavusgile@bus.msu.edu (E. Cavusgil), steven.phelan@unlv.edu (S.E. Phelan).

${ }^{1}$ Tel: +15174325535 .

2 Tel.: +1 7028952789 .
}

financial outcomes (Webster, Malter, \& Ganesan, 2003). The magnitude of this problem is such that the Marketing Science Institute made assessing marketing productivity (return on marketing) and marketing metrics the top research priority in 2002, 2004 and 2006. This is significant because the MSI serves as a bridge between the academic and practitioner communities in marketing. Also, the Journal of Marketing devoted an entire issue to measurement of marketing productivity in 2004.

The response from academics has differed with regard to how to approach the challenge of measurement. Some researchers followed the track of fortifying the present accounting measures that are being used. Chief among these approaches has been the economic value added (EVA) (Stewart, 1993), a perspective that goes beyond simple accounting measures and considers expenditures as investments that should be evaluated in line with the return on the investment. Other researchers have taken a different approach and attempted to formulate non-accounting metrics that can be used in conjunction with the already available accounting and financial metrics. This perspective recognizes the value of intangible assets. Early examples of these types of metrics include the Balanced Scorecard Approach (Kaplan \& Norton, 1992), and the more recent trend in marketing of measuring customer equity (CE) (e.g., Blattberg \& Deighton, 
1996; Rust, Zeithml, \& Lemon, 2000) and customer lifetime value (CLV) (e.g., Jackson, 1989; Jain \& Singh, 2002).

The present study first delineates the drivers behind the need for marketing metrics. These include corporate demand for accountability; discontent with traditional metrics; and the availability of IT and the Internet infrastructure. Then, a conceptual framework with seven critical dimensions is proposed for systematic examination of measurement efforts. An elaboration of these dimensions should assist scholars in making future contributions to measurement of marketing productivity.

\section{Why marketing metrics are a top priority}

Several key internal and external forces have elevated the importance of measuring marketing productivity. These are explicated below.

\subsection{Corporate trend for greater accountability of value-added}

At a time when firms are cutting costs, it is essential for all functional disciplines within the firm to be financially accountable. This introduces the need for measurement, as without measurement it is impossible to be accountable. For firms to measure the return on marketing, it is essential for them to treat marketing expenditures as an investment (Schultz \& Gronstedt, 1997). Traditionally many firms have viewed marketing as a short-term expense (Rust, Lemon, \& Zeithaml, 2004) to be indulged when finances are plentiful, and cut in times of hardship. However, only through treating marketing expenditures as an investment can marketing be compared to other tangible and intangible assets enabling the marketing function to play a role in the strategy of the firm (Schultz \& Gronstedt, 1997). In this way, issues of financial accountability can be addressed (Moorman \& Rust, 1999).

The treatment of marketing as an investment entails more than just the existence of financial metrics. Another condition that needs to be satisfied is that of defining the causal linkages between marketing and financial outcomes. In the past, marketing metrics were often seen as stand alone items to be achieved independently of other measures. Thus, for example, a company might set targets for market share, gross contribution, and customer satisfaction. However, to truly measure the return on marketing, scholars and practitioners must develop metrics that explicitly link all aspects of marketing performance together akin to the causal chains suggested by Ambler, Kokkinaki and Puntoni (2004). In addition, these causal models are incorporating microlevel customer data to model individual consumer behavior (Kale, 2004) thus allowing marketers to evaluate investment decisions at the individual customer level. This allows marketers to move away from older models of marketing investment which tended to aggregate both financial and non-financial measures across customers (Rust, Zeithaml, \& Lemon, 2004).

\subsection{Discontent with traditional metrics}

Traditionally, accounting tools such as the balance sheet and income statements have been used to measure performance.
However, recent extant literature (e.g., Ittner \& Larcker, 1998; Kaplan \& Norton, 1992) cites increasing dissatisfaction with these traditional metrics.

Conventional measures of productivity tend to be historical and do not provide information that can be used to assess the long-term future performance of the firm (Ittner \& Larcker, 1998). While historical measurement of performance may be better than none, it does not allow for the assessment of impact that may take some time to resonate. The past performance of a firm is no predictor of future performance, thus historical measures have limited usefulness. If firms are to move away from considering marketing as an expense toward marketing as an investment, then it makes sense that returns on marketing need to be captured in a longer-term context. Thus the metric should be forward-looking and have a long-term perspective to avoid the tendency to maximize short-run performance at the expense of long-run wealth creation (Laverty, 1996).

Next, accounting metrics fail to reflect the value of the intangible assets held by a firm (Bayon, Gutsche, \& Bauer, 2002; Sawhney \& Zabin, 2002) and can be misleading and out of step with the skills and competencies used and required by the knowledge-intensive businesses of today (Kaplan \& Norton, 1992). Today intangible assets are worth, on average, $69 \%$ of the firm's total market value as compared to $17 \%$ in 1978 (Sawhney \& Zabin, 2002). If marketing expenditures are an investment, and the creations of marketing are assets, then it is of utmost concern that these assets be valued by metrics in use. Likewise, should the metrics be misleading, this can lead to a plethora of problems, including rash investments based on inaccurate heuristics; or the canceling of certain programs that are deemed unsuccessful by virtue of the misleading measure.

In addition, scholars have expressed concern as to the accuracy of subjective measures of performance, the potential bias these subjective measures cause (McMullan, Chrisman, \& Vesper, 2001; Moers, 2005), and the often immaterial relationship between subjective measures and financial performance (Hogan et.al., 2002). In the past, marketers have relied heavily on subjective measures of performance, particularly in the areas of customer attitudes, product attributes, brand associations, and customer satisfaction. However, subjective opinions arise from marketing actions rather than the reverse. As such, while these measures may perform a useful control function, by signaling the need for corrective action if a measure starts to fall, the reality is that subjective measures will likely lag changes in the underlying objective attributes of the market offering. For instance, although Cadillac's brand equity has slowly eroded its product quality problems were evident decades ago. Similarly, objective declines in customer service and cleanliness at McDonald's restaurants may take years to broadly affect perceptual measures.

Finally, implicit in the extant literature has been a demand for relative metrics, i.e., those that consider the actions of competitors as well as the focal firm. Game theory states that value is co-determined by the actions of the firm and its rivals (Brandenburger \& Nalebuff, 1995). In addition, according to the resource-based view, competitive advantage (and thus firm value) arises from sustained differentiation from rivals (Barney, 
1991; Srivastava, Fahey, \& Christensen, 2001). The implication is that any metric that attempts to determine financial value (whether through causal chains or not) will be fundamentally flawed if it does not consider the actions of competitors as well as the focal firm.

\subsection{Availability of IT and Internet Infrastructure}

The corporate drivers of new metrics and discontent with traditional metrics would not have been sufficient, by themselves, for the realization of new metrics. A technological component is also necessary. The technology that facilitates the existence of these new metrics began with the Internet and Information Technology, and developed to include a firm's intranet and extranet. In addition to these, the prevalence of Enterprise Resource Planning (ERP) software, Customer Relationship Management (CRM) software and Electronic Cash Registers (ECR) allows firms to perform the necessary monitoring that enable the use of alternative metrics. Among others, newer information technologies allow for panel data that provide firms with immediate, timely metrics. The seven basic components of the CRM system (Winer, 2001), starting with the creation of the database of customer activity clearly outline the possibilities for marketers to use newer metrics. Winer (2001) gives the example of Thomson Holidays, a British tour company. As a result of its CRM activities, this company is able to measure profit per customer trip. The CRM database also provides information on brand loyalty allowing firms to target customers accordingly. CRM can also provide metrics for processes, technology, and people (Crosby \& Johnson, 2001).

As a result of these key internal and external forces, nontraditional measures are required that will enable managers to measure performance in a more accurate fashion. These measures will need to address the objective financial value of intangible assets; have a long-term, forward-looking perspective; be able to incorporate data with a micro-level granularity; provide a value that allows for comparison with competitors; and causally link marketing investments to financial outcomes.

\section{Measurement philosophy: where we have been and where we need to be}

The previous discussion highlights the need for a systematic re-examination of marketing metrics. As we look forward for improved measures, we need to provide guidelines for the formulation of better measures. The following discussion identifies and elaborates seven themes or dimensions along which marketing metrics should evolve. These themes are generated from the previous discussion on why marketing metrics are a priority. We comment on the nature of these changes, provide the rationale, and highlight issues that still need to be resolved. This framework is then applied to a representative set of marketing metrics in the next section to illustrate the shifts in measurement philosophy and outline a set of future challenges for researchers and practitioners.

\subsection{From non-financial to financial}

One of the key reasons for performance measurement is to obtain timely feedback so that corrective actions can be taken (Ambler, Kokkinaki \& Puntoni, 2004). Arguably, by speaking the same financial language as the rest of the firm, senior management can obtain a greater understanding of marketing initiatives, intervene more quickly when value creation is slowing, and take appropriate remedial action. In the past, the relationship between various non-financial measures and firm performance was unclear and financial performance often lagged changes in non-financial measures. Often, the promised financial payoffs from improvements in intermediate measures failed to appear. Senior management is now demanding that marketing actions are rendered in terms of financial impact and that marketing investments overcome the same financial hurdles as other types of investment.

The lack of clarity between non-financial measures and firm performance also presented opportunities for agency problems between senior management and marketers. Agency costs arise when the agent (in this case, marketers) has more information about their behavior than the principal supervising the agent (Ambler et.al., 2004; Bergen, Dutta, \& Walker, 1992). The sheer breadth of non-financial/intermediate marketing metrics made it possible for marketing managers to duck accountability by continuously altering the portfolio of metrics being used to present themselves in a positive light. Moreover, the achievement of intermediate measures such as market share and customer satisfaction has been manipulated by unscrupulous marketers in the past to collect bonuses and promotions while promised financial outcomes have not occurred or even resulted in serious financial losses for the parent firm (the spurious link between market share and profit popularized by the BCG matrix, and the resultant chase for market share comes to mind). The use of a single financial measure to monitor marketing performance makes it much more difficult to 'game' the system in these ways (Morrison \& Wensley, 1991).

Finally, there has been a perception among marketers that they have been seen as a 'soft' discipline whose investment recommendations have not been taken seriously by senior management during resource allocation processes. By embracing the tougher accountability standards of financial measures, marketers also stand to gain increased legitimacy and credibility with senior management that may see more resources allocated to value-enhancing marketing initiatives (Rust, Ambler, Carpenter, Kumar \& Srivastava, 2004a).

\subsection{From backward-looking to forward-looking}

As the old adage goes, managing by historical performance is like trying to drive by looking in the rear view mirror. Clearly, if the future competitive environment is going to be different from the past then there is some benefit in creating forward-looking estimates rather than relying on historical performance. At the same time, this hints at the fundamental problem, namely how to create metrics that are based on more than just projecting past results inflated by an uplift factor. 
Such estimates need to take into account factors such as changing competitive dynamics, environmental shifts, and internal initiatives, such as new product launches and brand extensions. The reality is that while many companies express a desire to develop forward-looking metrics, most still rely on traditional historical metrics, such as product contribution, revenue, and gross margin (Ambler et al., 2004; Barwise \& Farley, 2004).

\subsection{From short-term to long-term}

As noted previously, perhaps the major benefit of adopting a long-term perspective is the focus on maximizing long-run wealth creation rather than on maximizing short-term gains (Laverty, 1996). In fact, it has long been noted in marketing that marketing actions, such as advertising and promotion, have both a short-term and long-term effect on firm sales (Jedidi, Mela, \& Gupta, 1999). The shift to long-term performance metrics seeks to formalize these observations.

The challenge, of course, is that the longer the forecast horizon, the more heroic the assumptions that have to be made in preparing the estimates. All sorts of uncertainties arise in the competitive and macro environments, including the potential for new entrants, new technologies, or new regulations. Often, the forecaster assumes that the firm will be able to renew its sources of competitive advantage indefinitely into the future and thus preserve current margins, although evidence points to the fact that competitive advantage tends to decline over time (Jacobsen, 1988). Constructing a valid basis for future projections of marketing performance will continue to test academics and practitioners.

\subsection{From macro to micro data}

It is not too difficult to think of cases where the use of average tendencies of consumer behavior may mask important shifts among customer segments or even individual consumers. For instance, a small loss of market share might conceal the fact that a significant number of high contribution individuals have defected to the competition. Ostensibly, then, the modeling of individual consumer behavior should enable better forecasts and decisions.

Many companies will find that they do not have the microlevel data needed to drive the latest marketing metrics. Ceteris paribus, most marketers would prefer that their data had greater granularity but the reality is that the decision to collect more data is a business decision subject to the same cost-benefit analysis as any other investment. Many companies have often discovered that the low entry price of customer relationship management (CRM) software was "... swamped by the additional expenses of training, data collection, data analysis, information dissemination, and implementation programs" (Rigby \& Ledingham, 2004, p. 127). These costs will act as a barrier to the diffusion of more sophisticated marketing metrics unless other tangible benefits can be found to offset the costs of data collection (e.g., through greater sales and service efficiencies).

\subsection{From independent metrics to causal chains}

Moving from independent metrics to causal chains would yield major breakthroughs in the areas of efficiency and control. Using these models, marketing strategies and tactics could be directly evaluated by their effect on the bottom line and the most profitable courses of action selected. Furthermore, the model would generate predictions of the effect of these actions on intermediate variables such as customer attitudes and market share. To the extent that the intermediate variables would act as leading indicators of financial performance in the model, the strategies could be controlled and monitored through intermediate variables and corrective action taken to improve financial performance before problems were seen in the financial results.

The downside is that few studies currently exist on the effect of strategic and tactical actions on intermediate variables that then predict long-run financial performance. The causal relationship between marketing actions and financial returns is still not well understood. In the physical sciences, such relationships can be explored through formal experimentation, with its emphasis on controlled environments and systematic manipulation of variables of interest. In marketing science, it is impossible to conduct such controlled studies because companies (and their environments) are beyond the control of researchers. This suggests that casual analysis will be slow to develop and tentative in its conclusions.

\subsection{From absolute to relative}

Firms do not exist in a vacuum, thus value is co-determined by the focal firm and its competitors (Lippman and Rumelt, 2003). In addition, the extant literature on competitive advantage shows that firms derive competitive advantage from sustained differentiation from rivals (Barney, 1991; Wernerfelt, 1984). The use of relative metrics rather than absolute metrics will allow managers to contrast performance with that of the firms' competitors. However, obtaining competitor information on the plethora of marketing metrics used by the firm will remain problematic. Obtaining causal relationships between relative marketing performance and firm value may prove even more difficult. One solution may be to simplify the data gathering requirements by using a proxy for competitive advantage such as price premium. Researchers have demonstrated that price premium is a useful measure of brand health and brand equity (Ailawadi, Neslin, \& Lehmann, 2003). Another solution may be to invest in extensive benchmarking studies where competitors pool information and report average levels of activity on key metrics while remaining anonymous (Vorhies \& Morgan, 2005).

\subsection{From subjective to objective}

As a result of the aforementioned dissatisfaction with subjective measures, objective measures have come more to the fore. It is likely that product and service attributes (relative to competitors) are probably the most important driver of customer 
Table 1

Existing approaches to measurement critiqued on the seven dimensions ${ }^{\mathrm{a}}$

\begin{tabular}{|c|c|c|c|c|c|c|}
\hline & EVA & Balanced scorecard & $\begin{array}{l}\text { Brand equity } \\
\text { (financial perspective) }\end{array}$ & $\begin{array}{l}\text { Brand equity } \\
\text { (consumer psychology perspective) }\end{array}$ & Relational equity & Customer equity \\
\hline 1. Financial & Yes & Partial & Yes & No & Partial & Yes \\
\hline 2. Forward looking & No & Partial & Yes & No & Partial & Yes \\
\hline 3. Long-term & No & Partial & Yes & Partial & Partial & Yes \\
\hline 4. Micro & No & No & No & Partial & No & Yes \\
\hline 5. Relative & No & No & No & No & No & No \\
\hline 6. Causal & No & No & No & No & No & Yes \\
\hline 7. Objective & Yes & Partial & Yes & No & Partial & No \\
\hline
\end{tabular}

${ }^{\text {a }}$ Two academics independently reviewed the metrics on each dimension. The inter-rater reliability was $100 \%$.

perceptions (Wiggins \& Raboy, 1996). In fact, there is evidence that the informational power of the Internet is making objective attributes $^{3}$ more important and that brand loyalty is on the decline (Bennet \& Rundle-Thiele, 2005; Blumenthal, 2005; Surowiecki, 2004). Brand equity will still be important but will flow from the expectations of further positive experiences that arose from consuming a bundle of attributes that exceeded expectations rather than a blanket loyalty to a single brand; something Surowiecki (2004) refers to as the "what have you done for me lately' consumer philosophy.

The implication is that tracking, controlling, and planning changes in objective attributes both within the company and visà-vis competitors will become increasingly important to marketing performance and productivity. Often, this will require marketers to work across functional boundaries. For instance, some researchers are already recognizing the need for marketers to closely co-ordinate their efforts with co-workers in product development, supply chain management, and customer service to improve shareholder value (Srivastava, Shervani, \& Fahey, 1999). The trend for marketers to get more involved in the measurement and planning of business processes is only likely to accelerate in the coming years.

\section{Approaches to measurement in marketing}

In this section, we apply the above framework to critique the most common marketing metrics that have been proposed by scholars and used by practitioners. Due to space constraints it is impossible to discuss all of the metrics; however, the metrics critiqued represent those most popular in the business world and the extant scholarly literature. For example, EVA is an extensively utilized metric in corporate America and the balanced scorecard was being used in some form by $75 \%$ of Fortune 1000 firms in 2002 (Kumar, Sarkar, Saxena, Ripathi, \& Moller, 2002). In the extant marketing literature the recent trend has been to measure returns on marketing through the various equities (brand, customer, relational,) that have been proposed. Table 1 provides an outline of the critique based on the measurement philosophy detailed above.

\footnotetext{
${ }^{3}$ Note that objective attributes are not just physical attributes, but incorporate the full gamut of product, service, and relational attributes, including product quality, service quality, and purchasing experience.
}

\subsection{Economic value added}

For researchers that sought to strengthen the accounting metrics, Economic Value Added (EVA) is one method that has been widely espoused. It is still an accounting metric but is seen by its proponents as advancement over the more traditional ones. It is defined by Stewart (1993) as the difference between a firm's net operating income after taxes and its cost of capital of equity and of debt. Advocates of EVA claim that focusing on EVA as a performance measurement leads to improved stock performance as compared to focusing on the traditional accounting measures. Investment options are seen as favorable, when the EVA is greater than zero. When the EVA is less than zero then this investment option would be regarded unfavorably.

With regard to the seven evolving dimensions, EVA is financially based and objective. Therefore, we can argue that the use of EVA allows marketers to communicate outside of the marketing department and increases the legitimacy of the marketers in the eyes of the other functional areas within the firm. In addition, the lack of subjectivity in the measurement of EVA also aids the credibility. However, in relation to our framework, EVA still has several weaknesses.

First, this metric is historical and suffers from many the same problems as other traditional accounting metrics. It has a shortterm rather than a long-term orientation; and it focuses on results without offering any solutions (Brewer, Chandra, \& Hock, 1999). Also, the use of EVA does not allow marketers to infer causal relationships between the marketing decisions made and the impact of these decisions upon firm value. In fact the use of EVA will provide an independent measure of the value of an investment option. Likewise, if we examine EVA in light of micro and macro then it is not a measure that makes use of micro data and thus conclusions to be made are limited. EVA provides us with an aggregate value of the investment not one on a customer-by-customer basis. The final criticism from the framework is that EVA is not a measure that can be used to compare investment across companies. Thus through the use of EVA, firms are not able to consider performance relative to competitors.

\subsection{The balanced scorecard}

In response to the realization that the value of firms is dependent upon both tangible and intangible assets, Kaplan and 
Norton (1992) proposed the use of the balanced scorecard. Through the use of this tool, the manager is able to take a broad look at the whole organization from four differing perspectives. These perspectives are the customer perspective, the innovation and learning perspective, the internal business perspective, and the financial perspective. These perspectives provide the manager a more comprehensive view of all these different areas to improve the evaluation procedures taking place in a firm.

The balanced scorecard incorporates forward-looking metrics particularly with regard to the innovation and learning perspective. Proponents argue that these metrics of innovation and improvement will measure the drivers of the firm's longterm performance. In this regard, the balanced scorecard is at least partially forward-looking and partially geared toward the long-term performance of the firm. In addition one of the sets of measures within the balanced scorecard is financial thus ensuring partial financial measures. However, the balanced scorecard does not allow for any causal interpretations to be made as to the direct impact of marketing actions on the longterm financial performance of the firm. Also, as with EVA, the balanced scorecard measures at the aggregate level, thus not allowing the marketer to interpret the results at an individual customer level. There has also been no allowance for comparison with competitors and in its present state, the balanced scorecard only allows for an absolute measure.

\subsection{Brand equity}

One of the first endeavors to measure intangible assets specific to marketing was brand equity. Much attention (e.g., Aaker, 1991; Baldinger, 1990; Byron, 1995; Farquhar, 1990) was devoted to this issue in the early 1990s. Of the different streams of research in brand equity, the consumer psychology stream and the financial stream have dominated. Even though both these streams purport to measure the same concept, brand equity, there are crucial differences that necessitate that we evaluate them separately.

Aaker $(1991,1996)$ and Keller (1993) are probably the two most widely accepted models of brand equity based on the consumer psychology perspective. According to Aaker (1991, 1996), the measurement of brand equity can be undertaken using loyalty measures, perceived quality/leadership measures, associations/differentiation measures, and awareness measures. The loyalty measures include measures of behavior, switching costs, satisfaction, liking and commitment. The dimensions of perceived quality differ, depending on whether it is perceived product quality or perceived service quality. For products, the dimensions are performance, features, conformance with specifications, reliability, durability, serviceability, and fit and finish. For services, the dimensions are tangibles, reliability, competence, responsiveness, and empathy. The next dimension is brand association. Aaker (1991) mentions 11 different types of associations including country, competitor, application and relative price. The final dimension that Aaker (1991) discusses is brand awareness. Awareness is the customers' ability to recognize that brand as part of his/her choice set for a particular product. Levels of awareness were given as a pyramid (Aaker,
1991) with unaware of the brand at the bottom, moving up to brand recognition then brand recall and finally top of mind. Keller (1993) then proposes the dimension of brand image. This is split into characteristics of brand associations and relationships among brand associations. The characteristics include type, favorability, and strength. The relationships include uniqueness, congruence, and leverage.

The consumer psychology perspective is a mix of objective and subjective measures with predominance toward subjective measures. It acknowledges micro-level data as the measures are aggregated from individual customers, although the final measure itself is an aggregate brand-level measure. It is not a relative measure and instead provides an independent measure for each brand that does not allow for causal inference due to the cross-sectional nature of the data collected. It is generally shortterm oriented although arguments can be made that some of the measures (e.g., switching costs, commitment) lend themselves to a longer-term orientation. Most of the measures are not financial and most are historical in nature. The behavior measures and measures of liking, for example, are all based on past experiences that the customers have had with the brand and not on future experiences the customers my have.

The financial stream on measuring brand equity pays more attention to objective measures, and less to the subjective measures of the consumer psychology stream. One financial approach to measuring brand equity was undertaken by Simon and Sullivan (1993). These authors used financial data showing the profits stemming from the brand and thus estimating the firm's overall brand equity. In this way the authors made use of objective, financial data to calculate the value of the brand equity. Another advantage of such an approach is that it allows for comparison across companies, as the same financial data are available for both the firm and all its competitors. It is also a long-term measure in that it measures the impact of brand equity on the market value of a firm. Market value is a forward-looking measure incorporating the value of the future returns. Thus, this financial measure of brand equity is both forward-looking and has a long-term perspective. With regard to our conceptual framework the only two dimensions where this measurement of brand equity is deficient is in its lack of causality and in the fact that it provides measurement in the aggregate.

\subsection{Relational equity}

There has been a shift in marketing since the early 1990s, toward relationship marketing (e.g., Morgan \& Hunt, 1994). This has tied in with calls to move beyond the study of the dyad to the study of the network (e.g., Achrol, 1997). Relationship marketing involves four different types of partnerships: supplier partnerships, lateral partnerships, internal partnerships and buyer partnerships (Morgan \& Hunt, 1994). Within these types of partnerships we have several different relational exchanges and we can thus define relationship marketing as, "all marketing activities directed toward establishing, developing, and maintaining successful relational exchanges" (Morgan \& Hunt, 1994, p. 22). The concept of relational equity (Sawhney \& Zabin, 2002) draws on this to define it as "the wealth-creating potential that 
resides in the firm's relationships with its stakeholders" (p. 313). The authors propose a broad measure of relational equity including the relationships with channel partners, employees, suppliers, and customers. They believe that none of these stakeholder groups operate in isolation and, as such, a holistic view of relational equity is required. They propose the use of the Relational Maturity Model (RMM), which is based on the Capability Maturity Model (CMM), combined with a use of the scorecard approach. Their Relational Equity Scorecard (RES) provides holistic measures to focus on the quality of the relationships.

A detailed examination of the scorecard enables the analysis of these authors' conceptualization of relational equity in line with our framework. The authors suggest a variety of measures to be used for the scorecard with most of them being nonfinancial although there are measures of customer acquisition cost, customer lifetime value, and supplier cost. Also, the majority of the measures proposed are historical in their orientation, whether they are based on past performance, supplier productivity, or various types of satisfaction. Arguably there are only two types of forward-looking measures: employee based, i.e., those measuring employee skills and education level; and customer lifetime value (CLV). These same measures appear to be the only ones with a long-term focus, with the employee measures impacting upon the long-term performance of the firm and CLV purporting to measure the long-term value of customers to the firm. As with the balanced scorecard, the relational equity does not explain the causal linkages to performance and it does not provide relative metrics that can be compared with competitors. It is also primarily dependent upon macro data and provides information in the aggregate and generally of a subjective nature.

\subsection{Customer equity}

Customer equity is posited as an alternative to brand equity that reflected the fact that the focus of the firm should be on the customer and not the brand. It was initially introduced to mainstream marketing by Blattberg and Deighton (1996) in a paper that claimed the marketing manager's function was to balance the amount spent on retaining old customers and attracting new customers at the point where customer equity is at a maximum. Lemon, Rust and Zeithaml (2001) and Rust, Zeithaml and Lemon (2000) expanded on this concept and posited that there were three drivers of customer equity. The first of these, value equity is what the customer believes the utility of the brand to be. Second, brand equity is the customer's assessment of the brand over and above the perceived value. Finally, retention/relationship equity is the loyalty of the customer to the brand. The challenge for marketing managers would be to find which of the three drivers would be the dominant driver of customer equity for their firm. The actual calculation of customer equity is performed by summing of all a firm's customer lifetime values.

Customer equity is calculated as the sum of customer lifetime values and as such is both financial and forward-looking. The customer lifetime value metric professes to calculate the value of a customer from entry to exit thus showing the effect of marketing efforts over the long term. In addition, Rust and colleagues (2004) have been able to build a causal chain showing the return on marketing. This causal chain links the marketing investment to the increase in CLV and subsequently to the increase in customer equity. The same authors have also been able to operate at the micro level as they first calculate the individual CLV for each customer and then aggregate upwards. However, the authors have as yet been unable to model a relative value of customer equity. There are also limitations as to how objective the calculation of CLV is.

\section{Conclusion}

The analysis of the metrics in line with the conceptual framework does not provide one specific metric that fulfills all of the criteria. As such, there is no one metric at the present time that fits the requirements of the modern metric, i.e., satisfies all seven criteria. One suggestion for marketing managers is to consider the use of a basket of metrics that among them would encompass all of the dimensions. As an example, marketing managers may use a combination of customer equity and relational equity as between them they satisfy six of the seven dimensions in the framework. Of course, we did not claim that the metrics we analyze are an exhaustive list and, as such, combinations of metrics not incorporated in this analysis can also be considered. However, we believe that the proposed framework is a useful vehicle for managers to evaluate candidate metrics they wish to utilize.

It is crucial that managers and scholars alike continue to focus on the issue of measuring the returns on marketing and endeavor to satisfy all seven dimensions of the framework. Through these efforts, marketers can use metrics that help to reposition marketing expenditures as investments and answer the problems raised by scholars and practitioners alike, of how to measure the return on investment in marketing. If marketers are able to link marketing to financial outcomes, then problems of lack of representation in the boardroom and marketing having limited input into strategy formulation (Srivastava et.al., 1998), may soon be in the past. The invention of rigorous metrics to measure the return on marketing may provide the impetus for marketing to regain its place in corporate boardrooms worldwide.

\section{References}

Aaker, D. A. (1991). Managing brand equity. New York: The Free Press. Aaker, D. A. (1996). Measuring brand equity across products and markets. California Management Review, 38(3), 102-120.

Achrol, R. (1997). Changes in the theory of interorganizational relations in marketing: Toward a network paradigm. Journal of the Academy of Marketing Science, 25(1), 56-71.

Ailawadi, K. L., Neslin, S. A., \& Lehmann, D. R. (2003). Revenue premium as an outcome measure of brand equity. Journal of Marketing, 67(4), 1-17.

Ambler, T., Kokkinaki, F., \& Puntoni, S. (2004). Assessing marketing performance: Reasons for metric selection. Journal of Marketing Management, 20(3/4), 475-498.

Baldinger, A. (1990). Defining and applying the brand equity concept: Why the researcher should care. Journal of Advertising Research, 30(3), 2-5.

Barney, J. (1991). Firm resources and sustained competitive advantage. Journal of Management, 17(1), 99-120. 
Barwise, P., \& Farley, J. U. (2004). Marketing metrics: Status of six metrics in five countries. European Management Journal, 22(3), 257-262.

Bayon, T., Gutsche, J., \& Bauer, H. (2002). Customer equity marketing: Touching the intangible. European Management Journal, 20(3), 213-222.

Bennett, R., \& Rundle-Thiele, S. (2005). The brand loyalty life cycle: Implications for marketers. Journal of Brand Management, 12(4), 250-263.

Bergen, M., Dutta, S., \& Walker, O. C. (1992). Agency relationships in marketing: A review of the implications and applications of agency and related theories. Journal of Marketing, 56(3), 1-24.

Blattberg, R. C., \& Deighton, J. (1996). Manage marketing by the customer equity test. Harvard Business Review, 74(4), 136-144.

Blumenthal, D. (2005). Why branding, as we know it, is about to collapse. Journal of Brand Management, 12(3), 148-150.

Brandenburger, A. M., \& Nalebuff, B. J. (1995). The right game: Use game theory to shape strategy. Harvard Business Review, 73(4), 57-71.

Brewer, P. C., Chandra, G., \& Hock, C. A. (1999). Economic value added (EVA): Its uses and limitations. S.A.M. Advanced Management Journal, 64(2), 4-12.

Byron, S. (1995). Brand equity and market-based assets of professional service firms. Journal of Professional Service Firms, 13(1), 3-13.

Clancy, K. J., \& Stone, R. L. (2005). Don't blame the metrics. Harvard Business Review, 83(6), 26-28.

Crosby, L. A., \& Johnson, S. L. (2001). High performance marketing in the CRM era. Marketing Management, 10(3), 10-11.

Farquhar, P. H. (1990). Managing brand equity. Journal of Advertising Research, 30(4), 7-12.

Hogan, J. E., Lehmann, D. R., Merino, M., Srivastava, R. K., Thomas, J. S., \& Verhoef, P. C. (2002). Linking customer assets to financial performance. Journal of Service Research, 5(1), 26-38.

Ittner, C. D., \& Larcker, D. F. (1998). Innovations in performance measurement: Trends and research implications. Journal of Management Accounting Research, 10, 205-238.

Jackson, D. (1989). Determining a customer's lifetime value. Direct Marketing, 5l(11), 60-63.

Jacobsen, R. (1988). The persistence of abnormal returns. Strategic Management Journal, 9(5), 415-430.

Jain, D., \& Singh, S. S. (2002). Customer lifetime value research in marketing: A review and future directions. Journal of Interactive Marketing, 16(2), 34-46.

Jedidi, K., Mela, C. F., \& Gupta, S. (1999). Managing advertising and promotion for long-run profitability. Marketing Science, 18(1), 1-22.

Kale, S. (2004). CRM failure and the seven deadly sins. Marketing Management, 13(5), 42-50.

Kaplan, R. S., \& Norton, D. P. (1992). The balanced scorecard - measures that drive performance. Harvard Business Review, 70(1), 71-79.

Keller, K. L. (1993). Conceptualizing, measuring and managing customer-based brand equity. Journal of Marketing, 57(1), 1-29.

Kumar, A., Sarkar, S., Saxena, A., Ripathi, A., \& Moller, M. (2002). Making outsourcing happen with balanced scorecard-a unification approach paper. http://e-commerce.mit.edu/papers/ERF/ERF206.pdf. Accessed on 17th October 2004.

Laverty, K. J. (1996). Economic "short-termism" the debate, the unresolved issues, and the implications for management practice and research. Academy of Management Review, 21(3), 825-860.

Lemon, K. N., Rust, R. T., \& Zeithaml, V. A. (2001). What drives customer equity? Marketing Management, 10(1), 20-25.

Lippman, S. A., \& Rumelt, R. P. (2003). A bargaining perspective on resource advantage. Strategic Management Journal, 24(11), 1069-1086.

McMullan, E., Chrisman, J. J., \& Vesper, K. (2001). Some problems in using subjective measures of effectiveness to evaluate entrepreneurial assistance programs. Entrepreneurship Theory and Practice, 26(1), 37-54.

Moers, F. (2005). Discretion and bias in performance evaluation: The impact of diversity and subjectivity. Accounting, Organizations and Society, 30(1), 67-98.

Moorman, C., \& Rust, R. T. (1999). The role of marketing.Journal of Marketing, 63, 180-197 special issue.

Morgan, R. M., \& Hunt, S. D. (1994). The commitment-trust theory of relationship marketing. Journal of Marketing, 58(3), 20-38.

Morrison, A., \& Wensley, R. (1991). Boxing up or boxed in? A short history of the Boston Consulting Group share/growth matrix. Journal of Marketing Management, 7(2), 105-129.
Rigby, D. K., \& Ledingham, D. (2004). CRM done right. Harvard Business review, 82(11), 118-127.

Rust, R. T., Ambler, T., Carpenter, G. S., Kumar, V., \& Srivastava, R. K. (2004). Measuring marketing productivity: Current knowledge and future directions. Journal of Marketing, 68(4), 76-89.

Rust, R. T., Lemon, K. N., \& Zeithaml, V. A. (2004). Return on marketing: Using customer equity to focus marketing strategy. Journal of Marketing, 68(1), 109-127.

Rust, R. T., Zeithaml, V. A., \& Lemon, K. N. (2004). Customer-centered brand management. Harvard Business Review, 82(9), 110-118.

Rust, R. T., Zeithaml, V. A., \& Lemon, K. N. (2000). Driving customer equity: How customer lifetime value is reshaping corporate strategy. New York: The Free Press.

Sawhney, M., \& Zabin, J. (2002). Managing and measuring relational equity in the network economy. Journal of the Academy of Marketing Science, 30(4), 313-332.

Schultz, D. E., \& Gronstedt, A. (1997). Making Marcom an investment. Marketing Management, 6(3), 40-48.

Simon, C. J., \& Sullivan, M. W. (1993). The measurements and determinants of brand equity: A financial approach. Marketing Science, 12(1), 28-52.

Srivastava, R. K., Fahey, L., \& Christensen, H. K. (2001). The resource-based view and marketing: The role of market-based assets in gaining competitive advantage. Journal of Management, 27(6), 777-802.

Srivastava, R. K., Shervani, T. A., \& Fahey, L. (1998). Market-based assets and shareholder value: A framework for analysis. Journal of Marketing, 62(1), 2-18.

Srivastava, R. K., Shervani, T. A., \& Fahey, L. (1999). Marketing, business processes, and shareholder value: An organizationally embedded view of marketing activities and the discipline of marketing. Journal of Marketing, 63(4), 168-179.

Stewart, S. (1993). The Stern Stewart Performance 1000 Database Package: Introduction and documentation. New York: Stern Stewart Management Services.

Surowiecki, J. (2004, November). The decline of brands. Wired, 12, 205-209.

Vorhies, D. W., \& Morgan, N. A. (2005). Benchmarking marketing capabilities for sustainable competitive advantage. Journal of Marketing, 69(1), 80-94.

Webster, F.E., Malter, A.J., \& Ganesan, S. (2003). Can marketing regain its seat at the table? Marketing Science Institute MSI Reports, Working paper series (03-113), 29-47.

Wernerfelt, B. (1984). A resource-based view of the firm. Strategic Management Journal, 5(2), 171-180.

Wiggins, S. N., \& Raboy, D. G. (1996). Price premia to name brands: An empirical analysis. Journal of Industrial Economics, 44(4), 377-388.

Winer, R. S. (2001). A framework for customer relationship management. $\mathrm{Ca}$ lifornia Management Review, 43(4), 89-107.

Steven H. Seggie is an assistant professor of marketing at Bilkent University. His current research interests are interorganizational relationships and marketing metrics. He has previously published in the Journal of Business Research.

Erin Cavusgil is a doctoral student at Michigan State University. She holds a BS in Chemical Engineering from the University of Michigan and an MS in Biomedical Engineering from the University of Minnesota. She spent $31 / 2$ years working in the pharmaceutical industry as a chemical engineer. Her main area of research is new product development.

Steven E. Phelan is an associate professor of strategic management at the University of Nevada, Las Vegas. Dr. Phelan's research interests include competitive dynamics, organizational architecture, acquisition and alliance performance, and entrepreneurial competence. He has published extensively in journals such as the Strategic Management Journal, the Journal of International Business Studies, and Organizational Behavior and Human Decision Processes. 